
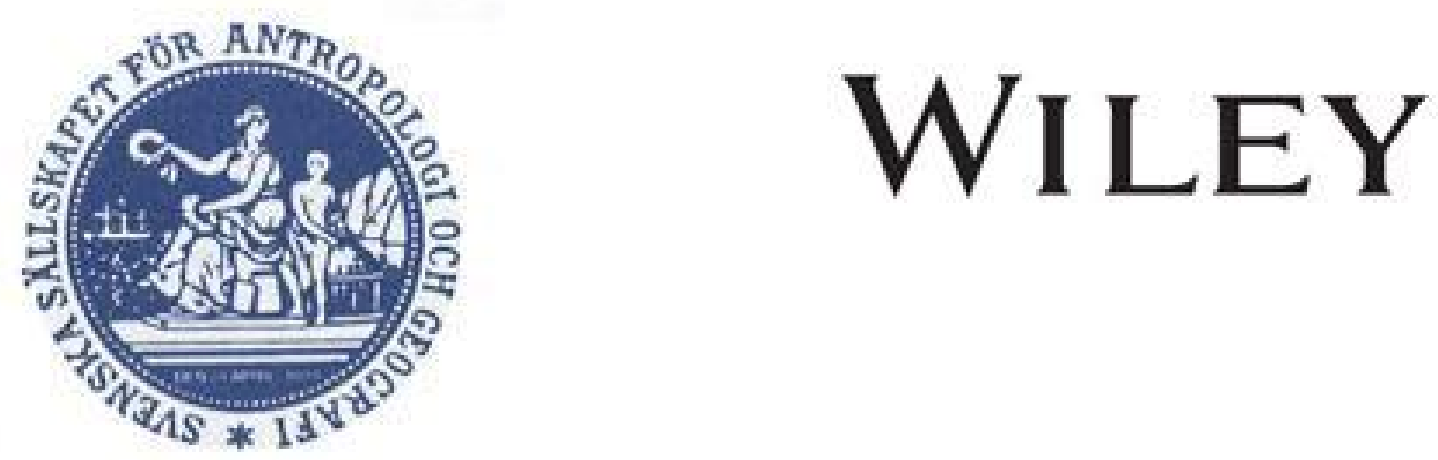

Continued Researches on the Height Variation of the Atmospheric Electric Potential Gradient

Author(s): Harald Norinder

Source: Geografiska Annaler, Vol. 4 (1922), pp. 116-121

Published by: Wiley on behalf of Swedish Society for Anthropology and Geography

Stable URL: http://www.jstor.org/stable/519739

Accessed: 25-06-2016 01:44 UTC

Your use of the JSTOR archive indicates your acceptance of the Terms \& Conditions of Use, available at

http://about.jstor.org/terms

JSTOR is a not-for-profit service that helps scholars, researchers, and students discover, use, and build upon a wide range of content in a trusted digital archive. We use information technology and tools to increase productivity and facilitate new forms of scholarship. For more information about JSTOR, please contact support@jstor.org.

Swedish Society for Anthropology and Geography, Wiley are collaborating with JSTOR to digitize, preserve and extend access to Geografiska Annaler 


\section{CONTINUED RESEARCHES ON THE HEIGHT VARIATION OF THE ATMO- SPHERIC ELECTRIC POTENTIAL GRADIENT}

BI HARALD NORINDER.

I $\mathrm{n}$ a previous work ${ }^{1}$ the author proved that in the lowest layers of the air the potential gradient was subject to a very marked increase with the height. The general opinion hitherto was that the potential gradient should decrease. The absolute mean value of the potential gradient at Upsala was also found to be lower than the mean value of Europe, a fact already established by the author in an earlier publication. ${ }^{2}$

The researches in question were carried out on a field situated near the Meteorological Institution at Upsala. The field was situated on the border of the town, naturally a not very conveniant locality for observations of atmospheric electricity. Therefore the author grasped the first opportunity of repeating his researches in a more convenient locality. The Royal Swedish Board of Waterfalls has established some research-stations for thunderstorms, and as the author is in charge of the investigations in question it was quite natural to continue the observations of the height variation of potential gradient at one of the thunderstorm stations.

The electric station, situated ro kilometres west of Upsala on the landed estate of Brunna was preferred for the purpose. The proprietor Mr. C. V. Rosenlund had with great courtesy alloted land for the station on one of his larger flat fields.

The location of the station in respect to surroundings is given in the map of fig. I, where the level lines per each half metre elevation are drawn. The map extends over an area around the point of observation of about twenty times the height of observations.

The little wood (at $D$ fig. I) consists of trees at about Io metres height and is not deep but continued by a greater field. The general location of the sta-

\footnotetext{
1 Height Variation of Electric Potential Gradient. Geografiska Annaler. Häft. I 1921. Stockholm I92I.

${ }^{2}$ K. Sv. Vetenskapsakademiens Handl. Bd 58 n:o 4. Stockholm I9I7.
} 
tion is a very open one. At $C, C_{1}$ (fig. I) there are some remote trees at a height of $6-8$ metres.

At the points $A, B$ fig. I are erected two posts 15 metres in height and 100 metres apart; at right angles to them are erected at $A_{1}, B_{1}$ fig. I two posts

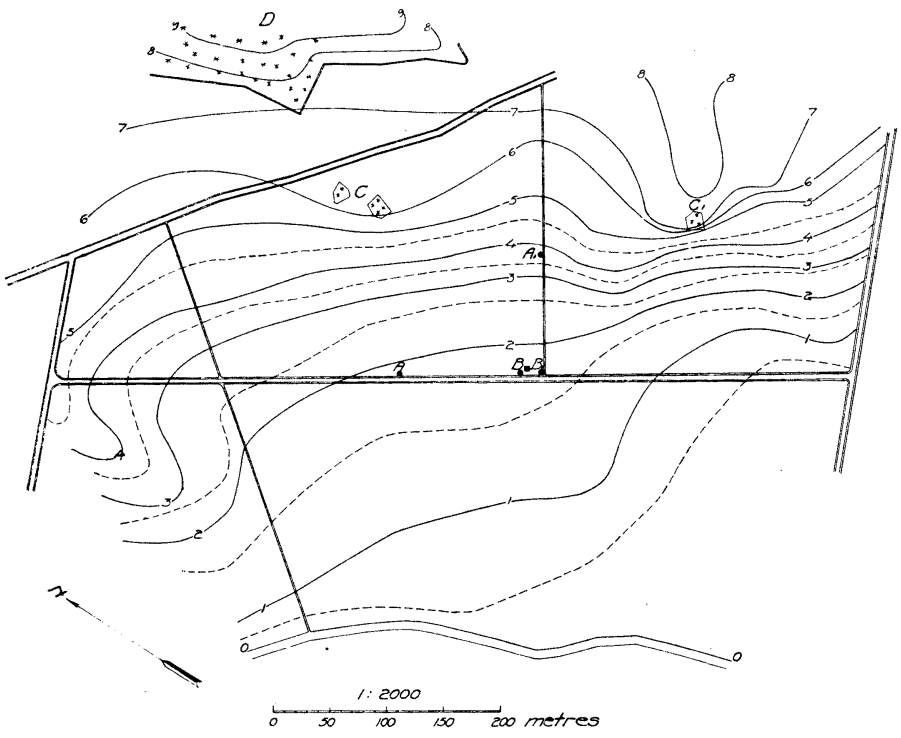

Fig. I. Map of the location of the Station. 9 metres in height. Near the post at $B$ is placed the instrument hut about 4 metres in height. Between the posts horizontal insulated steel wires were fixed, carrying convenient collectors at the middle. ${ }^{1}$ A general idea of the observation locality may be obtained from fig. 2.

In the middle of the steel wires were fixed high active polonium collectors, delivered during the summer of $192 \mathrm{I}$. For the following observations I 2 .IX8.X I92 I collectors were

used, on each wire with a polonium covered surface of 6 square centimetres on each wire, for later observations collectors with a poloniumcovered surface of 12 square centimetres on each wire.

By a simple manipulation the lower collector with wire and insulators could bechanged for the upper one and vice versa. When the systems in question were perfect it was not possible to observe any difference in potential gradient

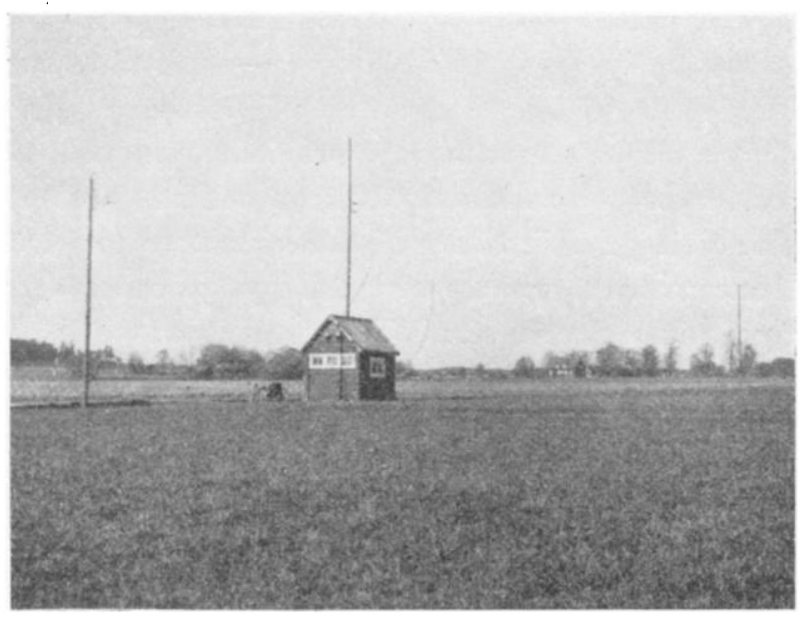

Fig. 2. The Station and its surroundings.

As to the special arrangements the reader is referred to the previous works of the author. 
Table $I$.

Individual Values of Potential Gradient at $0.5-13.25$

\begin{tabular}{|c|c|c|c|c|c|c|c|c|c|c|c|c|c|c|}
\hline Date & 12.9 & I 3.9 & I 3.9 & 14.9 & I 4.9 & 14.9 & 14.9 & 14.9 & I 4.9 & I 4.9 & I 8.9 & I 8.9 & 27.9 & 27.9 \\
\hline Time & $\begin{array}{l}6.50 \mathrm{p} \\
7.30 \mathrm{p}\end{array}$ & $\begin{array}{l}7.20 \mathrm{p} \\
7.50 \mathrm{p}\end{array}$ & $\begin{array}{l}8.0 \mathrm{p} \\
8.3^{\circ} \mathrm{p}\end{array}$ & $\begin{array}{l}10.50 \mathrm{a} \\
\mathrm{I} I .20 \mathrm{a}\end{array}$ & $\begin{array}{l}0.0 \mathrm{p} \\
0.30 \mathrm{p}\end{array}$ & $\begin{array}{l}1.35 \mathrm{p} \\
2.0 \mathrm{p}\end{array}$ & $\begin{array}{l}6.10 \mathrm{p} \\
6.50 \mathrm{p}\end{array}$ & $\begin{array}{l}\text { 7.rop } \\
\text { 8.0 p }\end{array}$ & $\left|\begin{array}{ll}10.5 & p \\
10.30 & p\end{array}\right|$ & $\mid \begin{array}{l}10.50 \mathrm{p} \\
\mathrm{I} 1 \mathrm{I} .30 \mathrm{p}\end{array}$ & $\begin{array}{r}9.40 \mathrm{a} \\
\mathrm{I} 0.20 \mathrm{a}\end{array}$ & \begin{tabular}{|l|}
$0.45 \mathrm{a}$ \\
$\mathrm{I} \mathrm{I} .30 \mathrm{a}$
\end{tabular} & $\begin{array}{l}5.10 \mathrm{p} \\
5.4^{\circ} \mathrm{p}\end{array}$ & $\begin{array}{l}6.301 \\
7.01\end{array}$ \\
\hline $\begin{array}{c}\text { Height m } \\
0.5\end{array}$ & 41 & 8 & 8 & 39 & 39 & 56 & $3 \mathrm{I}$ & 22 & 55 & 31 & 5.5 & 59 & 76 & $6 I$ \\
\hline 1.25 & 46 & I 8 & 22 & 40 & 50 & 31 & 28 & 33 & $4^{8}$ & 24 & 48 & 64 & $3^{I}$ & 33 \\
\hline 3.25 & 72 & 22 & 33 & $3 I$ & 42 & 33 & 31 & 37 & 37 & 20 & 72 & 98 & 40 & 24 \\
\hline 5.25 & 44 & $5^{2}$ & 59 & 33 & 44 & 37 & 42 & 46 & 55 & 31 & 55 & 72 & 39 & $3^{I}$ \\
\hline 7.25 & $6 I$ & 55 & 35 & 39 & 46 & 35 & 55 & 42 & 37 & 37 & 35 & 85 & 29 & 37 \\
\hline 9.25 & 77 & 39 & 40 & $5^{2}$ & 42 & 33. & 42 & 40 & i 37 & 55 & 64 & I I 4 & 39 & 42 \\
\hline I I .25 & - & 37 & 57 & 48 & - & 37 & 50 & 46 & - & 35 & - & - & 42 & - \\
\hline 13.25 & - & - & 66 & 18 & - & - & 55 & 44 & - & - & - & - & - & - \\
\hline
\end{tabular}

\begin{tabular}{|c|c|c|c|c|c|c|c|c|c|c|c|c|c|c|}
\hline Date & 7.10 & 7.10 & 7.10 & 7.10 & 8.10 & 8.10 & 8.10 & 8.10 & 8.10 & 6.10 & 28.111 & 28.11 & 28.11 & 28. I I \\
\hline \multirow{2}{*}{ Time } & I I.50 a & $0.40 \mathrm{p}$ & $3.0 \mathrm{p}$ & $5 \cdot 3^{\circ} \mathrm{p}$ & $10.50 \mathrm{a}$ & I I.30 a & $4.25 \mathrm{p}$ & $5.20 \mathrm{p}$ & $5 \cdot 50 \mathrm{p}$ & $6.25 \mathrm{p}$ & I. ro $\mathrm{p}$ & $1.50 \mathrm{p}$ & $2.3^{\circ} \mathrm{p}$ & $2.50 \mathrm{p}$ \\
\hline & $0.3^{\circ} \mathrm{p}$ & I.ro $p$ & $3.20 \mathrm{p}$ & $6.10 \mathrm{p}$ & II.20 a & $0.5 \mathrm{p}$ & $5.0 \mathrm{p}$ & $5.40 \mathrm{p}$ & $6.20 \mathrm{p}$ & $6.55 \mathrm{p}$ & $\mathrm{I} .30 \mathrm{p}$ & $2.10 \mathrm{p}$ & $2.5^{\circ} \mathrm{p}$ & $3.20 \mathrm{p}$ \\
\hline \multicolumn{15}{|l|}{ Height $m$. } \\
\hline 0.5 & 90 & 89 & 84 & I09 & 86 & 97 & 33 & 28 & 28 & $4 \mathrm{I}$ & 42 & 46 & 44 & 25 \\
\hline I.25 & 94 & 96 & 72 & 63 & 99 & 57 & 0 & o & 24 & 6 & 49 & 42 & 49 & 44 \\
\hline 3.25 & $I 14$ & 120 & I 16 & 83 & 74 & 116 & 37 & 40 & $6_{3}$ & -6 & 76 & 66 & 66 & 59 \\
\hline 5.25 & $8_{5}$ & 129 & I I 4 & 96 & I 12 & 98 & 42 & 37 & I 16 & 35 & 66 & 63 & 73 & 52 \\
\hline 7.25 & 94 & I 23 & 109 & 140 & $5 \mathrm{I}$ & 35 & 94 & 103 & 109 & 68 & 71 & 73 & 56 & 56 \\
\hline 9.25 & I 10 & 123 & 143 & 70 & 96 & 57 & 127 & 68 & 103 & 39 & 68 & 73 & 54 & 54 \\
\hline II. 25 & - & I 2 I & 153 & 88 & - & 57 & I 36 & 86 & I I 4 & 24 & 73 & $6 I$ & $6 I$ & 66 \\
\hline 13.25 & - & - & 162 & I 23 & - & 24 & 162 & 105 & Iog & I I 2 & - & 39 & $5^{6}$ & 51 \\
\hline
\end{tabular}

before and after changing, provided that the observations in question were corrected for the variation of the potential gradient that occurred in the mean-while. The voltage differences of the collectors to earth were recorded by two Benndorf electrometers, which were kindly placed at my disposal by Professor Svante Arrhenius, Stockholm. The sensitiveness of the electrometers was tested by a Wulf electroscope with a system of suitable air condensers provided with a guard ring. ${ }^{1}$

The distance between the collectors was $12 . \mathrm{IX}-8 . \mathrm{X} 5 \mathrm{I}$ centrimetres and later on 44 centimetres. The observed potential gradient was always reduced to volts per metre.

In observing the height variation of potential gradient practical experience showed that it was most convenient to observe as quickly as possible through

\footnotetext{
1 The electroscope with air condensers was delivered by Günther et Tegetmeyer, Braunschweig.
} 
metres above Ground in Volts per meter. Brunna I92I.

\begin{tabular}{|c|c|c|c|c|c|c|c|c|c|c|c|c|c|c|c|}
\hline $5 \cdot 10$ & 5.10 & 5.10 & 5.10 & 5.10 & 5.10 & 5.10 & 6.10 & 6.10 & 6.10 & 6.10 & 6.10 & 6.10 & 6.10 & 7.10 & 7.10 \\
\hline $3.20 \mathrm{p}$ & $4.4 \circ \mathrm{p}$ & $5.20 \mathrm{p}$ & $5.50 \mathrm{p}$ & $6.25 \mathrm{p}$ & $7.15 \mathrm{p}$ & $8.0 \mathrm{p}$ & $3.15 \mathrm{p}$ & $4.0 \mathrm{p}$ & $4.50 \mathrm{p}$ & $5.4 \circ \mathrm{p}$ & $7.15 \mathrm{p}$ & 8.o $p$ & $8.30 \mathrm{p}$ & $10.20 \mathrm{a}$ & I I $1.5 \mathrm{a}$ \\
\hline $3.4^{\circ} \mathrm{p}$ & $5.20 \mathrm{p}$ & $5.50 \mathrm{p}$ & $6.20 \mathrm{p}$ & $6.50 \mathrm{p}$ & $7.45 \mathrm{P}$ & $8.30 \mathrm{p}$ & $3.45 \mathrm{p}$ & $4.50 \mathrm{p}$ & $5.3^{\circ} \mathrm{p}$ & $6.10 \mathrm{p}$ & $7.50 \mathrm{p}$ & $8.30 \mathrm{p}$ & $9.0 \mathrm{p}$ & $\begin{array}{lll}1 & 1 & \end{array} .0 \mathrm{a}$ & I I $30 \mathrm{a}$ \\
\hline 33 & 20 & I 6 & 9 & 6 & 105 & 86 & 105 & IOI & 70 & 59 & 104 & 86 & 64 & I I 4 & 90 \\
\hline 63 & 9 & 7 & 26 & 26 & 77 & 33 & I 5 & 22 & $3 \mathbf{I}$ & 59 & 77 & 33 & 59 & 66 & 59 \\
\hline 64 & $3 \mathrm{I}$ & 17 & 42 & 42 & 131 & $5^{2}$ & I I & 92 & 57 & I 12 & 131 & $5^{2}$ & 96 & $8_{3}$ & 123 \\
\hline 64 & 39 & 53 & 39 & 33 & I 34 & I 26 & 57 & 94 & 116 & I 16 & I 34 & 127 & 105 & 70 & I 29 \\
\hline 64 & $3 I$ & 50 & 53 & 52 & 90 & $6 S$ & 107 & 94 & 103 & 112 & 90 & 68 & I 58 & 125 & 158 \\
\hline 59 & 37 & 57 & 46 & 53 & 175 & 63 & 55 & IOI & 50 & 145 & 175 & $6_{3}$ & 92 & 96 & I 62 \\
\hline 57 & 42 & 50 & 57 & 39 & 142 & 105 & 72 & 145 & 99 & 178 & 142 & 105 & I 26 & 50 & 96 \\
\hline- & 37 & 50 & 77 & 24 & 132 & 92 & $8 \mathrm{I}$ & I 56 & I 2 I & I 56 & 132 & 92 & I 19 & 86 & - \\
\hline $28.1 \mathrm{I}$ & 2S. I I & 28. I I & 28.11 & 28.11 & 28. I I & 28.11 & 29.1 I & 29.11 & $29.1 \mathrm{I}$ & 29. II & $29.1 \mathrm{I}$ & 30.11 & 30.11 & 30.11 & 30.11 \\
\hline $3.5 \circ \mathrm{p}$ & $4.20 \mathrm{p}$ & $5.15 \mathrm{p}$ & $5.50 \mathrm{p}$ & $6.20 \mathrm{p}$ & $8.0 \mathrm{p}$ & $8.4^{\circ} \mathrm{p}$ & I. то $\mathrm{p}$ & 2. Iо $\mathrm{p}$ & $2.25 \mathrm{p}$ & $3.0 \mathrm{p}$ & $5.3 \circ \mathrm{p}$ & $10.55 \mathrm{a}$ & I I.30 a & $0.10 \mathrm{p}$ & $2.30 \mathrm{p}$ \\
\hline $4.20 \mathrm{p}$ & $5.0 \mathrm{p}$ & $5.45 \mathrm{p}$ & $6.15 \mathrm{p}$ & $7.0 \mathrm{p}$ & $8.30 \mathrm{p}$ & $9.15 \mathrm{p}$ & $\mathrm{I} .45 \mathrm{p}$ & $2.25 \mathrm{p}$ & $2.55 \mathrm{p}$ & $3.25 \mathrm{p}$ & $6.0 \mathrm{p}$ & I I .20 a & $0.10 \mathrm{p}$ & $0.40 \mathrm{p}$ & $3.15 \mathrm{p}$ \\
\hline 27 & $5^{\circ}$ & 56 & 7 & 23 & 46 & 23 & 46 & 46 & 46 & $3^{8}$ & 67 & 59 & 86 & 88 & 56 \\
\hline $6 I$ & $5^{8}$ & 54 & $5^{I}$ & i 21 & 34 & i 2 I & 68 & 73 & 73 & $6 I$ & 104 & $8 \mathbf{I}$ & 87 & I I 2 & $8 I$ \\
\hline 68 & 76 & 59 & 46 & 20 & 46 & 20 & 83 & 71 & 68 & 73 & I I 8 & 68 & 73 & 68 & $8 S$ \\
\hline 63 & 103 & 59 & $4 \mathrm{I}$ & 34 & 29 & 32 & 73 & $8 \mathrm{I}$ & 54 & 68 & $7 \mathrm{I}$ & 95 & 73 & 68 & 76 \\
\hline 46 & $\$ 8$ & 56 & 46 & 44 & 49 & 54 & 66 & $6 \mathrm{I}$ & 54 & 63 & 68 & 68 & $6 I$ & 66 & 88 \\
\hline 71 & 93 & 68 & 39 & 46 & 46 & 63 & 54 & 66 & 59 & 63 & 63 & 73 & 54 & 83 & 88 \\
\hline $8 I$ & 80 & 88 & 34 & 46 & 56 & $5^{I}$ & $6 I$ & $7 \mathbf{I}$ & 59 & 66 & $4 \mathrm{I}$ & 82 & 49 & 66 & $8_{5}$ \\
\hline- & - & 86 & - & 34 & 54 & $5^{I}$ & 59 & 59 & $4 I$ & 54 & $5 \mathrm{I}$ & - & 49 & - & 76 \\
\hline
\end{tabular}

the whole height interval. This was made possible by a little improvement in the arrangements. The hoisting ropes for the collector carriages were so arranged that the collector wires could be controlled by one winch near the instrument hut. By this time was saved. When the collectors had to be moved up or down useless disturbance around the collectors was avoided. The time necessary for observing the gradient 0.5 to 13.25 metres above the ground was also shortened by observing only two minutes at each height interval $0.5,1.25,3.25-$ I 3.25 metres. When possible consecutive observation series were taken on the same day of observation. In table $\mathrm{I}$ the individual values of the potential gradient observed at Brunna are given.

The values are in general found during normal conditions on days without special disturbance in form of precipitation, fog, low clouds, etc. The variability of the potential during the time of observation was controlled by the percentage voltage difference of two consecutive minute recording points at the same height 
above the ground. A tendency to relatively greater variability was sometimes found at the higher intervals and therefore the corresponding observations had to be omitted.

The observations include two periods:

I) $12 . \mathrm{IX}-8 . \mathrm{X} 192 \mathrm{I}$. On account of the retarded autumn, the values of this period may be regarded as typical for advanced summer conditions.

2) 28.XI-30.XI I92 I. During this period the ground was frozen and partly covered with snow around the observation locality. The values obtained are characteristic for autumn conditions.

By comparing consecutive observation series in tab. I we can find values of the potential gradient that seem to be very markedly influenced by the effect of ion absorption. During observations in the daytime the absorption of ions is not so pronounced as during observations in the evening. Therefore the height variation of potential in comparable observation series is not so striking during observations $10 \mathrm{a}-5 \mathrm{p}$ as for the later ones.

The mean values for the two periods of observation and for different height intervals (o-9.25 metres, $0-\mathrm{II} .25$ metres and $0-13.25$ metres respectively) are given graphically in fig. 3. For the sake of comparison, the corresponding gradient values of Upsala, for summer and for autumn - spring, are also reproduced in fig. 3. The first period of observation $\mathrm{I} 2 . \mathrm{IX}-8 . \mathrm{X}$ is to be found to the left in figure $3(\mathrm{a})$.

We can establish:

a) By fig. 3 (a) a very marked increase with height of the potential gradient at Brunna. This prevails also for Upsala. The difference in gradient variation of the two places is to be found nearest to the ground. The potential gradient in Upsala was proved to decrease nearest to the ground. My explanation of this fact was an outflow of positive ions in excess through the capillaries from the earth. At Brunna, contrary to Upsala, the locality of observation was surrounded by large freshly ploughed fields, which naturally involved a greater outflow of positive ions. Therefore the gradient decrease at Brunna is more marked than at Upsala. At Brunna the effect of the outflow of ions is supposed to reach 3-4 metres, and if we presume a curve with this effect eliminated it must be somewhat like the dotted one in fig. 3. The difference of absolute mean potential gradient values as illustrated by the Upsala curve of fig. 3 (a) and the dotted one of Brunna can be fully explained by the yearly variation of the potential gradient. The curve of Upsala also contains observations during the middle of summer.

b) By fig. 3 (b) a very marked increase of the potential gradient nearest to the ground at Brunna that is not to be found in the corresponding values at Upsala. This difference may be explained by the conditions of observation. 
At Brunna the values are found with the ground frozen and partially snowcovered, contrary to many observations at Upsala, which were influenced by an unfrozen ground and a more intense outflow of positive ions in excess. The height variation at Brunna and at Upsala agrees heigher up and the variation of the two localities is to be considered as a transition stage to winter conditions. Thus I have established that the height variation of the potential gradient,

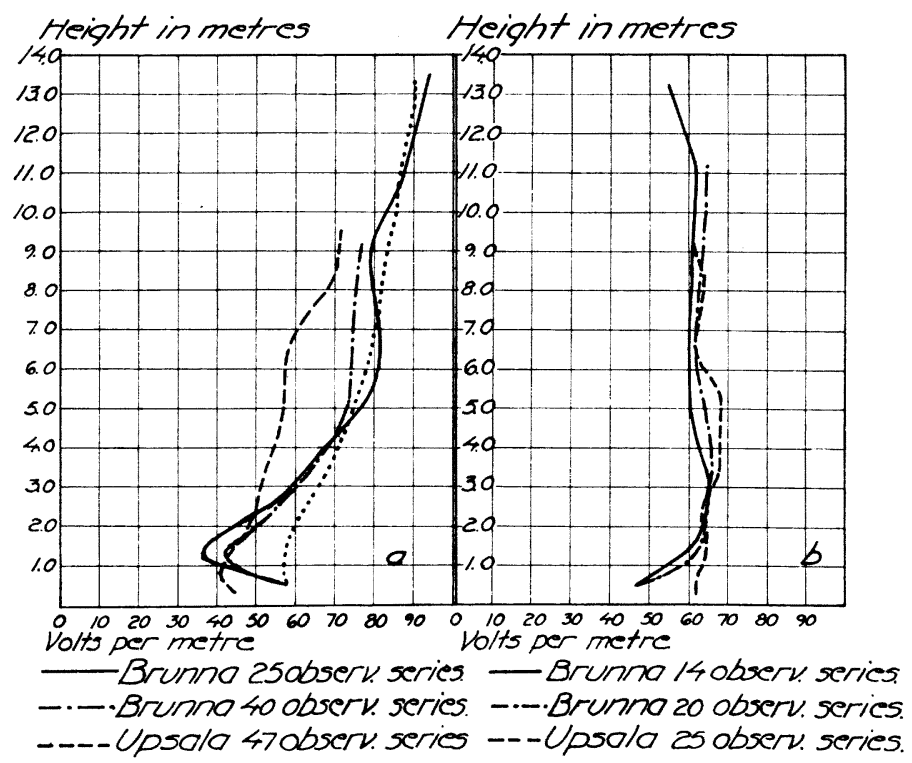

Fig. 3. Relation between Height and Potential Gradient.

that was the result of my investigation at Upsala also holds good for another locality of observation, where, owing to the absence of smoke and dust disturbances the observation conditions were more favourable. In the lowest layers of the air apart from the stratum nearest to the ground there prevails as a rule a negative volume charge in excess. According to the investigations the mean potential gradient at Brunna is, as was the case also at Upsala, considerably lower than the potential gradient that has been found as a mean value for Europe. 